PRZEGLĄD NAUK HISTORYCZNYCH 2018, R. XVII, NR 1

http://dx.doi.org/10.18778/1644-857X.17.01.05

DROBNE PRACE I MATERIAEY

SANDRA ORIGONE

Uniwersytet w GenuI*

\title{
Na krańcach cesarstwa wschodniorzymskiego - bizantyńska Liguria
}

\footnotetext{
Z
} azwyczaj, kiedy odwołujemy się do relacji między Genua, Liguria a Bizancjum, myślimy o kontaktach, które zostały nawiązane w XII w. Mniej znane sa stosunki między tymi krainami w okresie późnej starożytności, którymi zajmiemy się $\mathrm{w}$ tym artykule.

Od końca V do VII w. prefektura włoska znajdowała się w centrum ważnych przemian, spowodowanych najpierw dominacją Gotów, której kres położy rekonkwista bizantyńska w 553 r., a później zapoczatkowana w 568 r. inwazja longobardzką. Wpływ mierzacego się $z$ tym kryzysem cesarstwa na terytorium włoskim zmieniał się w zależności od okoliczności. Rzymskie granice stały się niestabilne i utraciły ścisła demarkację. W przypadku Ligurii, położonej nad morzem i otoczonej przez barbarzyński hinterland, poddanej ciagłym najazdom i zmniejszaniu się terytorium, należy mówić zatem o obszarze granicznym, charakteryzującym się $\mathrm{w}$ tamtym okresie wyraźnymi podziałami etnicznymi i kulturowym ${ }^{1}$. Skrajne wobec bizantyńskiego centrum położenie regionu nasuwa dwie powiązane ze soba kwestie, które zostana przeanalizowane w tym tekście. Pierwsza $z$ nich dotyczy intensywności bizantyńskiej obecności na terytorium w sferze religii, wojskowości i administracji. Druga koncentruje się na żywym zainteresowaniu cesarstwa obroną i utrzymaniem kontroli nad tym obszarem.

*Wydział Starożytności, Filozofii, Historii, e-mail: sandra.origone@lettere.unige.it.

1 N.J. Ch ris ti e, Byzantine Liguria: an Imperial Province against the Longobards. A.D. 568-643, „Papers of the British School at Rome” 1990, vol. LVIII s. 229-271. 
Znikoma liczba źródeł pisanych na temat sytuacji bizantyńskiej peryferii jest oczywista także w przypadku Ligurii. Dzieła o charakterze geograficzno-administracyjnym $z$ wieku VII stanowia kwestię dyskusyjną. W szczególności chodzi o tekst Descriptio orbis romani Jerzego $z$ Cypru, który przedstawia czasowy (między 580 a 590 r.) podział Italii na dystrykty administracyjne (pięć eparchii: Annonaria, Kampania, Kalabria, Emilia, Urbicaria), którego nie poświadczało żadne inne źródło. W tym nieuporządkowanym, znanym $z$ późniejszego zbioru $z$ IX w. tekście identyfikacja wymienionych miejsc nie zawsze jest łatwa i wywoływała liczne spory. Pozytywny pozostaje jednak fakt, że dzieło wymienia liczne miejscowości Półwyspu ${ }^{2}$. Sytuacja przedstawia się lepiej w przypadku tekstów o charakterze historiograficznym. Brakuje jednakże rozpraw poświęconych konkretnie sytuacji Ligurii, a nieliczne dostępne informacje skupiaja się zazwyczaj na wojskowości. Niemniej w części poświęconej wojnie gockiej w dziele Prokopiusza z Cezarei region ten pojawia się przynajmniej raz ze względu na morskie konotacje. Genua jest ceniona jako przystań dla statków płynących do Galii. Mówi się też o niej w kontekście wojsk bizantyńskich kierujących się do Mediolanu ${ }^{3}$. W przypadku epoki następującej po longobardzkim najeździe Paweł Diakon wymienia region wśród 16 włoskich prowincji ${ }^{4}$. Bazę naszych informacji uzupełniaja cytowane w dalszej części artykułu źródła.

Odkrycia archeologiczne (zabytki, monety, wytwory rzemieślnicze, kamienne inskrypcje) sugeruja historykom konieczność postawienia pytania o znaczenie tej epoki. Biorac pod uwage długi przedział czasowy, $z$ którego pochodza znaleziska, niemal nigdy nie jest możliwe określenie momentu ich powstania $z$ pełna dokładnością. Archeologicznie Liguria charakteryzuje się pozostałościami górskich castra, wśród których nie wszystkie są równie ważne i systematycznie zbadane, oraz rozwijajacymi się w okresie bizantyńskim ośrodkami nadmorskimi ${ }^{5}$. W temacie Ligurii oraz łączaccych

${ }^{2}$ Georgii Cyprii Descriptio orbis Romani, ed. H. Gelzer, Leipzig 1890.

${ }^{3}$ Procopii Caesariensis Opera Omnia, ed. J. Haury, Leipzig 1963, II, s. 203-204 (VI, 12). Autor ten nie wymienia jednak nazwy „Liguria” w kontekście pasa nadmorskiego, ale określa nią region transpadański.

${ }^{4}$ Pauli Historia Langobardorum, Monumenta Germaniae Historica, Scriptores Rerum Germanicarum, Hannover 1978, s. 96 (II, 15).

${ }^{5}$ S. Origone, Liguria bizantina: 538-643, [w:] Polupleuros Nous, Miscellanea für Peter Schreines zu seinem 60. Geburtstag, hrsg. von C. Scholz, G. Makris, Leipzig 2000, s. 272-289. 
ją $z$ cesarstwem aspektów wojskowych, religijnych i gospodarczych słuszne wydaje się przywołanie obserwacji Jonatana Shepparda na temat istotnej roli fortec i morskich baz, gdzie bizantyńscy funkcjonariusze mogli przygotowywać także niebezpośrednie kontrataki dzięki pomocy przekupionych luksusowymi towarami i innymi zachętami cudzoziemców ${ }^{6}$. Ta dostrzegalna w różnych peryferyjnych obszarach cesarstwa sytuacja dotyczy całego obszaru Włoch, w szczególności terytorium liguryjskiego w fazie bizantyńskiej rekonkwisty. Region okazał się bowiem do tego stopnia stłumiony obca agresją, że Bizantyńczycy musieli opuścić to terytorium wraz $z$ wybrzeżem toskańskim w 643 r., zatem ponad stulecie przed zakończeniem ich dominacji w Italii północnej wskutek longobardzkiego podboju Egzarchatu Rawenny (751).

\section{Struktura terytorialna}

Przede wszystkim należy określić liguryjskie terytorium, które $\mathrm{w}$ okresie gockim nie podlegało większym przemianom w stosunku do końca IV-poczatku V wieku, kiedy IX regio augustea (Liguria) rozszerzyła się do regio XI Transpadana, od wybrzeża Morza Liguryjskiego aż po Alpy. Goci Teodoryka, który podbił Italię w roku 493, nie wprowadzili zatem nowego ustroju. Świadectwa okresu gockiego (493-540) wspominają o głównych miastach tego regionu, dając do zrozumienia, że ich sytuacja się nie zmieniła. Gocki historyk Jordanes wspomina, że stolica Ligurii był Mediolan, zniszczony podobnie jak Pawia i inne pobliskie miasta przez najazdy Hunów. Odnosi się on także do innego miasta, które znajduje się między Mediolanem i Genua - Tortony ${ }^{7}$. Również Kasjodor, autor epistolarnego zbioru Variae, wspomina o magazynach z zapasami w Pawii i Tortonie, które były do dyspozycji Teodoryka ${ }^{8}$. Wiadomo, że jeszcze w okresie wojny gocko-bizantyńskiej starożytną via Postumia przemierzały od Genui do Mediolanu wojska bizantyńskie, które - wprawdzie na krótko - ale podbiły jednak także obszar za Padem 9 .

${ }^{6}$ J. Shepard, Bunkers, Open Cities and Boats in Byzantine Diplomacy, [w:] Byzantium, its Neighbours and its Cultures, ed. D. Dzino, K. Parry, Leiden 2017, s. 11-44.

${ }^{7}$ Iordanis Getica, ed. Th. Mommsen, Berlin 1882, 98 (30), 114 (42), 118 (45).

${ }^{8}$ Magni Aurelii Cassiodori Variarum libri XII, ed. A.J. Fridh, Corpus Christianorum, Series Latina, 96, Turnhout 1973, s. 408 (X, 27).

${ }^{9}$ Procopii Caesariensis Opera..., II, s. 203-204 (VI, 12). 
Granice prowincji zostały zmodyfikowane w szczególności w okresie najazdów longobardzkich, kiedy przez nazwę "Liguria” rozumiano jedynie obszar od Padu po Alpy $z$ wyłączeniem brzegu morza. Liguria transpadańska obejmowała Mediolan, Turyn i Pawię. Tak przynajmniej można wnioskować na podstawie świadectwa Pawła Diakona, który w swoim słynnym opisie podziału administracyjnego Półwyspu Apenińskiego klasyfikuje ówczesną Ligurię jako region transpadański, wtedy już utracony przez Bizantyńczyków, podczas gdy ośrodki nad Padem, czyli Acqui, Tortona, Bobbio, oraz miasta na wybrzeżu - Genua i Savona - wówczas wciąż w ręku Bizantyńczyków, należałyby do regionu określanego jako Alpes Cottiae (Alpy Kotyjskie) ${ }^{10}$, ze względów obronnych rozciągniętego aż do terenów liguryjskiego wybrzeża. Dzieło geografa znanego jako Anonim Raweński skupia się na jeszcze późniejszym okresie. Wzmiankuje o graniczacej z Galia „prowincji Maritima Italorum”, odpowiadajacej współczesnej Ligurii, w której granicach znajdowały się miasta Luni i Ventimiglia ${ }^{11}$. Nazwa ta odzwierciedlała sytuację, na której zaważyła ostatnia faza dominacji bizantyńskiej. Longobardowie zapanowali wówczas nad środkową częścią regionu, a później, w 643 r., wkroczyli do miast na wybrzeżu, takich jak Genua, Albenga, Savona, Varigotti i Luni, odebrali je cesarstwu i opanowali je ogniem i mieczem, jak w apokaliptycznym tonie opisuje kronikarz Pseudo-Fredegar ${ }^{12}$.

Zmienny obszar regionu w omawianym okresie gocko-bizantyńsko-longobardzkim pozwala zrozumieć, dlaczego termin "Liguria” przez długi czas nie był używany dla określenia strefy wybrzeża, mimo że region zwyczajowo był związany z litora. Przywołać można tu na przykład Izydora $z$ Sewilli (560-636). W Etymologiae opowiada on o legendarnej migracji Liguryjczyków na Korsykę. Urodzajna wyspa przyjęła nazwę pewnej liguryjskiej kobiety, która poprowadziła tam swój lud, podążajac za bykiem ze swojego stada. Mimo że wydarzenie to jest mitem, znaczace jest, że Liguryjczycy jawią się w nim jako zdolni do zamorskiej wyprawy ${ }^{13}$. Po zakończeniu longobardzkiej okupacji Królestwa Italii w późnym średniowieczu grani-

\footnotetext{
${ }^{10}$ Pauli Historia..., s. 97 (II, 16).

${ }^{11}$ Ravennatis Anonimi Cosmographia et Guidonis Geographica, ed. M. Pinder, G. Parthey, Berlin 1860.

${ }^{12}$ Fredegarius (pseudo), Chronicon, MGH, Scriptores rerum Merovingicarum II, ed. B. Krusch, Hannover 1988, IV, 71.

${ }^{13}$ Is id or o, Etimologie o origini, ed. A. Valastro Canale, vol. II, Turin 2006, s. $217(\mathrm{XIV}, 6,41)$.
} 
ce regionu zostały kompletnie zmodyfikowane, a jego terytorium, początkowo włączone do zarządu terytorialnego Królestwa Franków, w wieku X przeszło we władanie trzech dynastii marchialnych (Arduinica, Aleramica, Obertenga), których terytoria rozciągały się od krótkiego pasa wybrzeża ku centrum ${ }^{14}$. W końcu wraz z ukształtowaniem się genueńskiej komuny, która w ciągu XII w. przejęła kontrolę nad obszarem, region przybrał formę wybrzeża od Monako do Portovenere. Jednakże dopiero uczeni z XV w., zadajacy sobie pytania zarówno o aspekty etnograficzne, jak i o granice fizyczne tego obszaru, zaczęli utożsamiać Ligurię z obszarem wybrzeża. Genueński humanista Jacopo Bracelli, który swoją Descriptio orae Ligusticae $^{15}$ dał wzór innym autorom, np. swojemu rówieśnikowi Biondo Flavio, i zainspirował go do stworzenia dzieła Italia Illustrata (1474), rozumiał trudność rozstrzygnięcia tej kwestii na podstawie sprzecznych opisów starożytnych autorów. Unikając wyznaczania północnych granic regionu, opisał tylko część wybrzeża. W późniejszym okresie boloński geograf Leandro Alberti, który od Bracellego zaczerpnał materiał do swojego dzieła (Descrittione di tutta Italia, 1568), stwierdził, że region rozciagał się wzdłuż wybrzeża i docierał aż do Apeninów. Odpowiadał więc genueńskiemu dominium, districtus Ianue ${ }^{16}$.

\section{Społeczność wojskowa bizantyńskiej Ligurii}

Liguria stanowiła część cesarstwa graniczaca $z$ terytoriami frankijskimi Burgundii i Prowansji, których władcy byli zaangażowani w sprawy włoskie w czasie longobardzkich podbojów. Najpierw Grzegorz z Tours, a później Paweł Diakon opowiadali o relacjach Franków, Longobardów i Bizantyńczyków na spornym terytorium północno-zachodnich Włoch. Pierwsze spostrzeżenie dotyczy statusu Ligurii, która pozostała bizantyńska i możemy ją sobie wyobrażać jako dobrze chroniona lub chociażby pozostająca na uwadze cesarstwa. Wydaje się prawdopodobne, że aż do tego okresu Longobardowie, zamiast poszerzać swoje wpływy na nizinie kontrolowanej przez Bizantyńczyków, dążyli do przejęcia odcinka alpejskiego.

${ }^{14}$ T.O. De Negri, Storia di Genova, Firenze 1985, s. 190-193.

${ }^{15}$ G. Balbi, L'epistolario di Iacopo Bracelli, Genova 1969, 26. Por. G. Pis tarin o, La Liguria: regione nazione, [w:] La capitale del mediterraneo, Bordighera 1993, s. 5-33.

${ }^{16}$ Por. G. Andriani, Giacomo Bracelli nella storia della geografia, „Atti della Società Ligure di Storia Patria” 1924, vol. LII, s. 155-161. 
Często zatem wchodzili w konflikty z Frankami. Wiadomo także, że według planów cesarza Maurycjusza sojusz z królem Austrazji Childebertem w zamian za 50000 solidi miał doprowadzić do klęski Longobardów. Frankijski historyk, zgodnie $z$ tym, co przekazał historyk Longobardów, Paweł Diakon, dodaje, że Childeryk, przybywszy do króla do Włoch $z$ niezliczonym wojskiem Franków (cum innumera Francorum multitudine), zamiast $z$ nimi walczyć, zawarł porozumienie w Longobardami, wywołując gniew bizantyńskiego cesarza, który domagał się zwrotu wyłożonych 50000 solidów $^{17}$.

W okresie egzarchatu, między 594 a 599 r., Longobardowie nacierali na Nizinę Padańską i Piemont, napotykając na bizantyńskie stanowiska obronne strzegące wybrzeża. W tej fazie szczególnego znaczenia nabrały ufortyfikowane osady połączone $z$ ośrodkami liguryjskiego wybrzeża, które chroniły połączeń morskich ${ }^{18}$. W tym syntetycznym ujęciu sytuacji polityczno-terytorialnej regionu oczywista jest waga kwestii militarnej i na tej podstawie, przy ograniczonych źródłach, zadajemy sobie pytanie, kim byli Bizantyńczycy obecni w Ligurii i co oznaczało dla nich znalezienie się na krańcach imperium. Jasne jest, że w większości byli żołnierzami. Bizantyńska klasa wojskowa, która nigdy nie była zbyt liczna, także w Ligurii była tylko częściowo zgrecyzowana, czasem była pochodzenia łacińskiego bądź zlatynizowana. Dokładniejsze informacje pochodzą ze wskazówek dostarczanych przez źródła pisemne (inskrypcje i autorzy $z$ tamtego okresu) na temat pochodzenia etnicznego poszczególnych grup i postaci. Przykładowo: w 538 r. do Ligurii na ratunek Mediolanowi zostało wysłanych tysiące Izauryjczyków i Traków pod dowództwem Enesa i Pawła ${ }^{19}$; do Albengi, miasta na wybrzeżu liguryjskim Lewantu, przybył comes i trybun Tzittas, dowódca lokalnego garnizonu, być może Ormianin ${ }^{20}$; w Luni pojawił się magister militum Aldio, który był dowódca oddziału złożonego $z$ nieochrzczonych cudzoziemców, prawdopodobnie pogan ${ }^{21}$;

${ }^{17}$ Gregorio di Tours, Storia dei Franchi. I Dieci Libri delle Storie, ed. M. O1doni, vol. II, Milano 1980, s. 80-3 (VI, 42), 198-201. Por. anche Pauli Historia..., s. 72 (XVII).

18 S. Origone, La Liguria nell'età dell'esarcato, „Porphyra” 2006, Issue 8, s. 12-25, www.porphyra.it.

${ }_{19}$ Procopii Caesariensis Opera..., II, s. 203 (VI, 12).

${ }^{20}$ CIL V, 7793; G. M e n nella, G. C o c colu to, Regio IX. Liguria reliqua trans et cis Appenninum, Bari 1995, 43.

${ }^{21}$ S. Gregorii Magni Registrum epistolarum, vol. II, ed. D. Norberg (Corpus Christianorum, Serie Latina, CXL A e B), Tutnhout 1982, B, s. 655 (IX, 103). 
w Genui przebywał prawdopodobnie łaciński archont lokalnego garnizonu, niejaki Bono, wnuk Giovanniego, który zastapił w wikariacie prefekta Wigiliusza ${ }^{22}$. Wskazuje się także na miles Magnus $\mathrm{u}$ władzy numerus Illyricorum wspominanych w inskrypcji datowanej na rok $590^{23}$. Grekiem mógł być stratelates Basilio, do którego należy pieczęć odnaleziona w nadmorskim miasteczku Varigotti ${ }^{24}$. Jak zostało wskazane, ogółem do wojsk bizantyńskich w Italii ${ }^{25}$, zatem także do Ligurii, zostały wysłane oddziały złożone $z$ różnych narodowości i wyznań. Nie wiemy, jaka część $z$ nich wróciła do swoich miejsc pochodzenia, a jaka skorzystała $z$ sytuacji wojennej i zdecydowała się pozostać, przyczyniając się do niezwykłej różnorodności etnicznej Ligurii.

Wojska Bizancjum służyły w środowisku chrześcijańskim, łacińskim i zlatynizowanym. Bizantyńskie oddziały już w okresie gockim utrzymywały kontakty $z$ miejscową ludnością. Przypadek Sisigisa, gockiego dowódcy garnizonu Alp Kotyjskich, który w 539 r. musiał podporządkować się bizantyńskiemu komendantowi Tomaszowi, potwierdza hipotezę o przekształceniu gockich budowli w twierdze, zatem o ponownym ich wykorzystaniu przez Bizantyńczyków. Opowiedziane przez Prokopiusza z Cezarei następujace potem wydarzenia, czyli oddanie Bizantyńczykom alpejskich twierdz gockich, potwierdzają niestabilność zaludnienia tych miejsc $^{26}$. Twierdze zamieszkiwały prawdopodobnie wojska stacjonujące wraz z ludnością miejscowa, autochtonami, którzy żyli tam ze swoimi rodzinami i zaciagali się do wojska okupanta. Przyczyny kontaktów między oddziałami a ludnością miejscowa były wielorakie. Kasjodor pisze, że oderwana od swych siedzib i zwykłych zajęć miejscowa ludność miała za zadanie zaopatrzenie wojsk goc$\mathrm{kich}^{27}$. Prawdopodobnie nastapiło to później także w czasie wojny bizantyńsko-longobardzkiej. W rzeczywistości źródła mówią niewiele o tej lokalnej społeczności, która również zaciagała się do

${ }^{22}$ Procopii Caesariensis Opera..., II, s. 338 (VII, 10).

${ }^{23}$ CIL V, 7771. G. Mennella, G. Coccoluto, Regio IX..., 27.

${ }^{24}$ G. Murialdo, Conclusioni: Il castrum di S. Antonino nell'Italia nord-occidentale in età bizantino-longobarda, [w:] Sant'Antonino: un insediamento fortificato della Liguria bizantina, ed. T. Mannoni, G. Murialdo, Bordighera 2001, s. $764-765$.

${ }^{25}$ S. Cos en tino, Storia dell'Italia bizantina (VI-XI secolo). Da Giustiniano ai Normanni, Bologna 2008, s. 115-118, 150-155.

${ }^{26}$ Procopii Caesariensis Opera..., II, s. 280-281 (VI, 28).

${ }^{27}$ Magni Aurelii Cassiodori Variarum..., s. 408 (X, 27). 
wojska. Strategikon Pseudo-Maurycego, traktat na temat bizantyńskiej strategii wojskowej końca VI w., zdaje się upamiętniać wojnę przeprowadzona w Italii przeciw Longobardom. Jest to widoczne zwłaszcza wtedy, kiedy mówi się o taktyce obranej przeciwko tym jasnowłosym ludom i radzi się, aby używać w walce $z$ nimi metod wojny partyzanckiej. Stawiano na zasadzki, potajemne manewry, fortele oraz udawane sojusze, tak by brak zaopatrzenia czy niedogodności spowodowane upałem czy zimnem stłumiły ich odwage i zapał. Dzieło to wspomina także o Liguryjczykach, wskazujacc na ich umiejętność walki w górach i terenach wyżynnych, podobną do tej, która szczycili się Hiszpanie ${ }^{28}$. Motyw listy maksym, które żołnierz musi mieć w pamięci, odnosi się oczywiście do literackiego toposu, który urzeczywistnił się podczas wojny w Ligurii. Konflikt toczył się na trudnym terenie. Bizantyńczycy czasem znajdowali się w silnej izolacji. Strategiczne punkty, które najdłużej opierały się longobardzkim najazdom, to twierdza w Suzie w Alpach, która upadła w 577 r., czy twierdza Chrysopolis na wyspie na jeziorze Como, zdobyta w latach 588-589.

Zniszczeniom wojennym przeciwstawiano nieustanne dzieło odbudowy i konstrukcji jednostek obronnych, prostych phylakai, czyli stanowisk wartowniczych (uważa się, że było nim Castellaro di Zignago w Ligurii), dzięki którym utrzymywano kontrolę nad droga, czy bardziej złożonych systemów obronnych, takich jak phrouria i kastra, które zapewniały obronę całej osadzie ${ }^{29}$. Najważniejsza i systematycznie badana przez archeologów pozostałością systemu obronnego jest twierdza Perti, górski kompleks położony w głębi Ponente Ligure przy miejscowości Finale. Według hipotez miał on podwójna funkcję: prymitywnego schronienia dla ludności wybrzeża, a następnie ośrodka wojskowego, ufortyfikowanego i umiejscowionego według strategicznego szkicu. Znaleziska, takie jak amfory, przywożone naczynia $z$ VI i VII w. oraz monety (dziewięć srebrnych i jedna miedziana), datowane na czasy Herakliusza, potwierdzają ciagłość kontaktów między bizantyńskimi wybrzeżami Morza Śródziemnego. W odróżnieniu od zaopatrzenia uzyskiwanego dzięki szerokiej sieci połączeń, która obejmowała wybrzeża północnej Afryki, obszar grecki i wschodni, przedmioty użytkowe i biżuteria, szczególnie kobieca, wskazują na obecność elementu

${ }^{28}$ Das Strategikon des Maurikios, ed. G.T. Dennis, tr. E. Gamillscheg, CFHB XVII, Wien 1981, s. 296-297, 368-371.

${ }^{29}$ S. Origon e, Liguria bizantina..., s. 272-289. 
tubylczego, tak jak na longobardzkich stanowiskach archeologicznych północnego wschodu aż po Słowenię. Obecność przebudowanej później, protoromańskiej kaplicy wewnatrz twierdzy w Perti zasugerowała archeologom hipotezę na temat istnienia wcześniejszego budynku kultu, po którym nie pozostały jednak żadne ślady, w funkcji ośrodka wojskowego. Wezwanie św. Antoninusa miałoby ponadto być połączeniem świętego wschodniego, Antoninusa z Apamei oraz świętego wojskowego, męczennika o tym samym imieniu $z$ legionu tebańskiego ${ }^{30}$.

\section{Wyznania w bizantyńskiej Ligurii}

Liguryjskie społeczeństwo tego okresu pod względem etnicznym i religijnym było zróżnicowane, co związane jest $z$ wyznawanym przez ludy germańskie arianizmem. Hermann Josif Vogt, wybitny specjalista w zakresie patrologii i historii Kościoła, podnosił kwestię końca dominacji germańsko-ariańskiej w czasie bizantyńskiej rekonkwisty Półwyspu ${ }^{31}$. W rzeczywistości jednak problem konwersji znajdował się w centrum uwagi papieża Grzegorza Wielkiego, który 30 lat po longobardzkiej inwazji martwił się rytuałem przejścia od arianizmu do chalcedońskiego wyznania wiary ${ }^{32}$. W Ligurii odnaleziono inskrypcje grobowe, które pozwalają na bliższą obserwację społeczeństwa liguryjskiego w VI i VII w., mimo że dają one informacje jedynie o najwyższych klasach społecznych. Stanowili je głównie dowódcy cywilni i wojskowi, kobiety $z$ wyższych warstw społecznych i ich dzieci, często zmarłe w dzieciństwie, bądź kobiety, które poświęciły się Bogu ${ }^{33}$. Religijność tej wspólnoty odzwierciedla się w sformułowanych stereotypowo inskrypcjach nagrobnych, na których widnieją klątwy przeciw profanacji nagrobka, świętokradczego czynu wyrządzanego zazwyczaj przez osoby innej wiary ${ }^{34}$. Jest prawdopodobne, że wspólnota ta obawiała się osób innego wyznania, którymi mogli być członkowie różnorodnego etnicznie

${ }^{30}$ Odwołujemy się tu do rezultatów badań archeologicznych przywołanych i skomentowanych przez G. Mu riald o, La contrazione insediativa altomedievale e l'abbadono del castrum, [w:] Sant'Antonino..., s. 669-682.

${ }^{31}$ H.J. Vogt, [w:] Storia della chiesa, Storia della chiesa, vol. III (La Chiesa tra Oriente e Occidente), ed. H. Jedin, Milano 1992, s. 341-345.

${ }^{32}$ Gregorii Magni Registrum..., A, s. 16 (I, 17).

${ }^{33}$ Por. np. G. Mennella, Regio IX, Dertona-Libarna, Bari 1990, nr 1, 10, 14, 15, 17, 23, 29, 40, 57; G. Mennella, G. Coccoluto, Regio IX..., 48, 58.

${ }^{34}$ Por. np. G. Mennella, G. Coccoluto, Regio IX..., nr 30, 43. 
bizantyńskiego wojska czy sami mieszkańcy tego obszaru, gdzie współistnieli ariańscy Goci i chalcedońscy Grecy. W przekroju społeczeństwa liguryjsko-bizantyńskiego obecna jest także greckojęzyczna mniejszość, poświadczona przez nieliczne, zniszczone inskrypcje znalezione w Genui i Tortonie, zapisane w języku greckim, niedatowane, ale szacowane na okres bizantyński ${ }^{35}$. Wiele znalezisk, w szczególności pochodzących z nadmorskiego miasta Albenga, jest datowanych według lat panowania cesarza bizantyńskiego, co wskazuje na więź instytucjonalna z Konstantynopolem. Obawa przed manifestowaniem własnej religijności widoczna w chrystogramach, krzyżach, formułach związanych z Trójca Świętą wskazuje natomiast na problematykę religijna, która przeniknięta była lokalna społecznośćc ${ }^{36}$. Znaczącym przykładem $z$ Albengi może być kamień nagrobny Honoraty, wdowy po comesie i trybunie Tzittanie, w którym obecne sa wszystkie wskazane cechy: przynależność do wysokiej klasy społecznej, powtarzalny motyw krzyża, datowanie według roku Justyna II i zaklęcie ${ }^{37}$. Lęk przed herezja znalazła artystyczny i doktrynalny wyraz w podniosłym, oficjalnym tonie aż do końca okresu gockiego w schematycznej ikonografii chalcedońskiej Baptysterium w Albendze. Przy jej budowie pracowali najprawdopodobniej wędrowni mistrzowie ${ }^{38}$. Mozaiki w Santa Maria di Luni wprowadzaja budynek w kontekst wpływów kulturowych, które rozciagają się aż po północną Afrykę (np. inskrypcja Geroncjusza, jednego $z$ siedmiu biskupów Tusci, adresatów listu Pelagiusza I z 557 r., gdzie papież nawoływał ich do tego, by przestali sprzeciwiać się potępieniu Trzech Dzieł czy innego Geroncjusza, który został ekskomunikowany przez papieża Wigiliusza za tę samą sprawę) $)^{39}$.

Miasta liguryjskie pełnia przede wszystkim funkcję połączeń drogowych. Albenga, położona na skraju via Julia Augusti, łączyła Rzym z Arles; Genua, punkt docelowy via Postumia, łączyła Ligu-

${ }^{35}$ Por. np. G. Mennella, op. cit., nr 98, 99, 100, 101, 102, 103, 104.

${ }^{36} \mathrm{Na}$ temat płyty Magnus z Genui, która przedstawia datę według ósmego roku panowania Maurycjusza i trzy symbole przypominajace krzyż, por. np. G. Mennella, G. Coccoluto, Regio IX..., 27.

${ }^{37}$ G. Mennella, G. Coccoluto, Regio IX..., nr 43.

${ }^{38}$ M. Marcenaro, Il battistero di Albenga. Le origini del primo cristianesimo nella Liguria marittima, Genova 1993.

${ }^{39}$ S. Lu suardi Sien a, La Cattedrale di Santa Maria, [w:] Luni. Guida Archeologica, Sarzana 1985, s. 120-130; ponadto por. Archeologia Cristiana, [w:] Liguria, Aree ed edifici di culto tra IV e XI secolo, Soprintendenza Archeologia della Liguria, Genova s.d., s. 1-4. 
rię i Akwileję, port na morskiej trasie do Galii; Luni i Ventimiglia łączyły krańce liguryjskiego szlaku via Aurelia. Ze źródeł wynikaja jednak także specyficzne funkcje: Albenga była ośrodkiem biskupim i bastionem wiary. Varigotti było prawdopodobnie siedziba garnizonu wojskowego. Kwitnące wówczas jeszcze Luni nie wykazywało oznak dekadencji i przyjmowało posiadająca dobra ziemskie wspólnotę żydowską i chrześcijańskich niewolników wykorzystywanych do pracy na roli. W ich sprawie interweniował Grzegorz Wielki i zalecał ich uwolnienie ${ }^{40}$. Genua, centrum administracyjne jako siedziba wikariatu, skorzystała także na obecności mediolańskiego metropolity Honorata, przeniesionego do Ligurii $z$ powodu longobardzkiej okupacji Mediolanu.

Organizacja religijna wspólnot w bizantyńskich dominiach, zagrożonych przez longobardzkich heretyków, wraz z przybyciem ariańskich Gotów pod koniec wojny ${ }^{41}$ staje się koniecznością. Krzyżuja się tu ortodoksja polityczna i religijna. Pod koniec VI w. siła lojalności politycznej przejawia się w szybkim zwalczeniu schizmy Trzech Rozdziałów. Po przystapieniu do niej Genua szybko pojednała się z Konstantynopolem, chociaż przez pewien okres północne terytoria regionu, poddane Longobardom, wykazywały opór przeciwko zwalczeniu schizmy. Mimo małej liczby źródeł należy podkreślić w tym czasie wspólnotę interesów między egzarchą a metropolita, którego poświęcenie wymagało odpuszczenia w debitum salutationis officium $\mathrm{w}$ stosunku do najwyższego przedstawiciela bizantyńskiej władzy w Italii, jak wnioskuje się $z$ procedury przed wyświęceniem prałata Costanzo ${ }^{42}$. Wszystko to wskazuje na religijne implikacje więzi Ligurii $z$ cesarstwem, a sfery kościelne były w nich uprzywilejowanym pośrednikiem.

\section{Aspekty ekonomiczne}

Gospodarka tej epoki wiąże się wybrzeżem. Przynależność do świata bizantyńskiego stworzyła warunki do ekonomicznego pobudzenia regionu, które było możliwe dzięki połączeniu z Prowansją i wyko-

40 S. Gregorii Magni Registrum..., A, s. 239 (IV, 21). Na temat społeczności żydowskiej w Genui por. Magni Aurelii Cassiodori Variarum..., s. 76 (II, 27), 163 (IV, 33).

${ }^{41}$ Agathias, Agathiae Myrinaei Historiarum libri quinque, ed. R. Keydell, Berlin 1967, s. 10.

${ }^{42}$ S. Gregorii Magni Registrum..., A, s. 174-175 (III, 29), 176 (III, 30), 177 (III, 31). Por. S. Origo ne, La Liguria nell'età dell'esarcato..., s. 18-19. 
rzystaniu genueńskiego portu w 538 r. podczas wojny przeciwko Gotom. Źródła materialne potwierdzają dynamikę rozwoju liguryjskiego wybrzeża w VI i VII w. Ważne znaleziska, takie jak inskrypcje na wschodnich marmurach, zdradzaja możliwe ponowne użycie wytworów rzemieślniczych czy też pozostałości antycznych i świadczą o świadomości wartości tych materiałów ze strony społeczności, która wciąż potrafiła je docenić. W szczególności pamiętne sa napisy nagrobne San Paragorio w Noli z VI-VII w. biskupa Teodora oraz $z$ Lidorii czy owalny kamień $z$ orłem wznoszącym się nad gromem z I-II w., odnaleziony w Perti ${ }^{43}$. Obiekty i naczynia pokazuja społeczność, która otaczała się wyposażeniem i ozdobami wysokiej jakości, takimi jak wyroby złotnicze i biżuteria $z$ Luni VI-VII w., grzebienie $z$ kości $z$ Luni, Genui i Noli ${ }^{44}$, lampiony z afrykańskiej gliny stemplowanej $z$ pierwszej połowy VII w., przywiezione do Genui, afrykański lampion w formie muszli z V-VI w., odnaleziony w Albendze, wykopaliska afrykańskiej ceramiki z VII w. w Albendze, Genui, Luni, Sant'Antonino di Perti, Savonie, Varigotti ${ }^{45}$. Znaczace sa ponadto monety z czasów Justyna II (565-578), Tyberiusza II Konstantyna (578-582), Fokasa (602-610), Herakliusza (610-641) w Sant'Antonino di Perti ${ }^{46}$, Maurycjusza (582-602) w Luni i Genui oraz Konstansa II (641-668) w Finalmarinie ${ }^{47}$.

Archeologia narzuca konieczność refleksji nad ciagłościa śródziemnomorskich relacji Ligurii, które wraz $z$ podbiciem Rotari absolutnie się nie zakończyła. Wpłynęły na nie jednak ogólne tendencje stopniowego zmniejszania się zasięgu dystrybucji ${ }^{48}$. Północna Afryka, zorganizowana wokół egzarchatu kartagińskiego, jawi się wciaż jako podstawa ciągłości bizantyńskich rynków na Morzu Tyrreńskim i stanowi czynnik, który tłumaczy rozwój Ligurii i wysiłki zmierzające ku jej obronie aż do roku 643. Po tej dacie nie organizowano już wypraw wojskowych w celu rekonkwisty. Nieregularne przepływy handlu z północną Afryką były kontynu-

${ }^{43}$ Roma e la Liguria Maritima: secoli IV-X. La capitale cristiana e una regione di confine, Atti del Corso e Catalogo della Mostra, Genova, 14 febbraio - 31 agosto 2003, ed. M. Marcenaro, Bordighera 2003, s. 273, nr 53.

${ }^{44}$ Roma e la Liguria Maritima..., s. 251, nr 7; 252, nr 9; 259, nr 25, 271 , $\mathrm{nr} 48$.

${ }^{45}$ Ibidem, s. 265, nr 32, 33; 282, nr 73.

${ }^{46}$ T. Mannoni, G. Murialdo, Sant'Antonino di Perti, s. 235-238.

${ }^{47}$ Roma e la Liguria Maritima..., s. 252, nr 11-11b; 268, nr 39a-39b, 40a-40b.

${ }^{48} \mathrm{E} . \mathrm{Z}$ an in $\mathrm{i}$, Le Italie bizantine. Territorio, insediamenti ed economia nella provincia bizantina d'Italia (V-VIII secolo), Bari 1998, s. 332. 
owane aż do islamskiego podboju egzarchatu Kartaginy w 698 r., na korzyść jednak oddziału longobardzkiego. Bizancjum uczyniło $z$ Ligurii jeden $z$ obszarów własnej interwencji administracyjnej i wojskowej, by zahamować najazdy barbarzyńskie. Wiele aspektów pozostaje jednak niejasnych. Wskazaliśmy na dowody potwierdzające istnienie miejscowej arystokracji, wciąż kształtującej się i otwartej na obce wpływy, jak potwierdzałyby to wspólnoty żydowskie Genui i Luni; mówiliśmy o obecności duchownych łacińskich, greckich dowódców wojskowych i wojsk obcego pochodzenia. Brakuje jednak informacji na temat relacji między miejscowymi a stolica egzarchatu, Rawenna, więzi - jeśli taka istniała - między wojskami stacjonującymi a terytorium, sposobu wynagrodzenia za służbę, korzystania $z$ wypłaty przez żołnierzy, kontaktów międzyetnicznych. Obraz społeczeństwa nie jest kompletny, ale dobrze przedstawia duże zaangażowanie cesarstwa w utrzymanie więzi instytucjonalnej, wojskowej i kulturowej $z$ oddzielająca się stopniowo częścia imperium. O ile wejście w skład cesarstwa odległej Ligurii umożliwiła fala zwycięstw, która pozwoliła Bizantyńczykom skupić się na froncie wschodnim i bałkańskim, to prawda jest także, że bizantyńskie doświadczenia miały wielkie znaczenie dla regionu, który mógł dzięki temu wykorzystywać aż po okres longobardzki marynarskie talenty mieszkańców. Warto przywołać mały, ale znaczacy epizod: przetransportowanie w 725 r. szczątków św. Augustyna $z$ Sardynii do Pawii za pośrednictwem portu w Genui ${ }^{49}$.

\section{Liguria w oczach bizantyńskich}

Historia przekazywana przez pewne źródło hagiograficzne mówi, że hieromnich Jakub udał się na Zachód w celu pielgrzymki lub tė̇, jak rzeczywiście się stało, by debatować z papieżem Sergiuszem II na temat zakończenia sporu ikonoklastycznego (843). W drodze do Galii zatrzymał się zatem w Genui, gdzie na zaproszenie biskupa Maxity pozostał przez 14 lat, zanim dotarł do Berry, gdzie zmarł w 865 r. ${ }^{50}$ Ta krótka biografia wpisuje się w obraz

${ }^{49}$ S. Origon e, La Liguria nell'età dell'esarcato, s. 22, gdzie cytowane sa inne źródła na temat kontaktów morskich w epoce Longobardów.

50 Vita S. Iacobi monachi et eremitae, [w:] Biturgibus, Acta Sancorum Ordinis Benedicitni, IV, 2, Paris 1680, s. 142-153. Na temat doświadczenia Jakuba por. P. Schrein er, Bisanzio e Genova. Tentativo di un'analisi delle relazioni politiche, commerciali e culturali, [w:] Orbis Byzantinus. Byzanz und seine Nachbarn, Buçuresti 2013, s. 65. 
religijno-kulturowych wpływów, które między światem bizantyńskim a zachodnim nigdy nie ustały i które potwierdziło zainteresowanie znajomościa greki we Francji w czasach Karola Łysego ${ }^{51}$. Przenikanie się kultur jest ważne, by móc zrozumieć pojawienie się w Genui marmurowych znalezisk, kapiteli z wieku X, których obecność mogłaby przeczyć idei drastycznego zerwania stosunków między Bizancjum a Ligurią. Były one prawdopodobnie utrzymywane w sposób niebezpośredni ${ }^{52}$. Wiadomo, że w czasach biskupa Liutpranda $z$ Cremony w X stuleciu mieszkańcy Wenecji i Amalfi handlowali szatami $z$ purpury ${ }^{53}$; Amalfitanie, Rzymianie i Neapolitańczycy sprzymierzyli się u boku biskupa Sigefreda w celu poparcia Konstantyna VII w walkach o tron w Konstantynopolu ${ }^{54}$. Ich obecność w stolicy była zatem znacząca, podczas gdy Genueńczycy wciąż byli dalecy od możliwości nawiązania kontaktów $z$ cesarstwem.

Jak wiadomo, dopiero w XII w. ponownie nawiązali oni kontakty, o których informowała po raz pierwszy Porfirogenetka Anna Komnena ${ }^{55}$. Obecność genueńską w Konstantynopolu zasygnalizował jednak wyłącznie historyk Jan Kinnam. Jego punkt widzenia jest szczególny. Patrząc w przeszłość $z$ antykwarycznym nastawieniem, autor powołuje się na sytuację administracyjna późnego cesarstwa, kiedy region transpadański zwany Liguri sięgał aż po morze. Wojna wypowiedziana następnie Longobardom w tym regionie odcisnęła niezatarty ślad w bizantyńskiej pamięci. Historyk zdaje sobie sprawę, że ów obszar terytorialny był zajęty przez Longobardów i używa określeń Lampardia i Lampardos, wyjaśniając, że są one synonimami słów „Liguria” i „Liguryjski”. Nawet mówiąc o Genueńczykach zjednoczonych z Wenecjanami w 1170 r. w ich dzielnicy w Konstantynopolu, nie używa wyrażenia „Genousioi”, ale określa ich jako Lombardczyków ${ }^{56}$. W tym punkcie trwające nieco ponad stulecie

${ }^{51} \mathrm{Na}$ temat kulturalnej atmosfery dworu karolińskiego i obecności greckich eremitów por. W. Bers hin, Medioevo greco-latino..., 152-159, 172.

${ }^{52}$ C. Dufour Bozzo, La diocesi di Genova, Corpus della scrittura altomedievale, IV, Spoleto 1966. Inni datuja te kapitele na wiek XI. Por. recenzja M. Viei1lard-Troiekur off w: „Cahiers Archéologiques” 1968, vol. XVIII, s. 263-266.

${ }^{53}$ Liutprandi episcopi Cremonensis Opera, ed. J. Becker, Hannover-Leipzig 1915, s. 205 (55).

${ }^{54}$ Ibidem, s. 143 (V, 21).

${ }^{55}$ A n n e Co m n e ne, Alexiade. Règne de l'empereur Alexis I Comnène, ed. B. Leib, Paris 1967, III, s. 46-47, 54 (XI, 11, XII, 1).

56 Kinnamos, Epitome rerum ab Ioanne et Alexio Comnenis gestarum, ed. A. Meineke, Bonn 1836, cc. 280, 282. 
starania na rzecz zachowania zanikajacej prowincji uwarunkowały geograficzno-historyczne podstawy i bizantyńskie słownictwo.

Przedstawiony obraz potwierdza, że Bizantyńczycy aż do końca istnienia cesarstwa podtrzymywali wobec Ligurii ideę imperialną. Przejawiała się ona we wpływie na ludność rzymską wywieraną przez zestaw czynników administracyjnych, kulturowych i religijnych. Poza obrona wojskowa był to najprawdopodobniej najskuteczniejszy środek wsparcia własnych interesów w takim regionie, jak Liguria, odległym od ośrodka podejmowania decyzji i władzy bizantyńskiej oraz otoczonym coraz bardziej agresywnymi i walecznymi cudzoziemcami.

\section{Z języka włoskiego przełożyła \\ KaTARZYNa KOWALIK UNIWERSYTET ŁÓDZKI}

\section{Bibliografia}

\section{ŹRÓDEA DRUKOWANE}

Agathias, Agathiae Myrinaei Historiarum libri quinque, ed. R. Keydell, Berlin 1967. Biturgibus, Acta Sancorum Ordinis Benedicitni, IV, 2, Paris 1680.

Comnene A., Alexiade. Règne de l'empereur Alexis I Comnène, ed. B. Leib, Paris 1967.

Das Strategikon des Maurikios, ed. G.T. Dennis, tr. E. Gamillscheg, CFHB XVII, Wien 1981.

Fredegarius (pseudo), Chronicon, MGH, Scriptores rerum Merovingicarum II, ed. B. Krusch, Hannover 1988.

Georgii Cyprii Descriptio orbis Romani, ed. H. Gelzer, Leipzig 1890.

Gregorio di Tours, Storia dei Franchi. I Dieci Libri delle Storie, ed. M. Oldoni, vol. II, Milano 1980.

Iordanis Getica, ed. Th. Mommsen, Berlin 1882.

Isidoro, Etimologie o origini, ed. A. Valastro Canalel, vol. II, Turin 2006.

Kinnamos, Epitome rerum ab Ioanne et Alexio Comnenis gestarum, ed. A. Meineke, Bonn 1836.

Liutprandi episcopi Cremonensis Opera, ed. J. Becker, Hannover-Leipzig 1915. Magni Aurelii Cassiodori Variarum libri XII, ed. A.J. Fridh, Corpus Christianorum, Series Latina, 96, Turnhout 1973.

** Instytut Romanistyki, Zakład Italianistyki, e-mail: katarzyna.kowalik@uni. lodz.pl. 
Pauli Historia Langobardorum, Monumenta Germaniae Historica, Scriptores Rerum Germanicarum, Hannover 1978.

Procopii Caesariensis Opera Omnia, ed. J. Haury, Leipzig 1963.

Ravennatis Anonimi Cosmographia et Guidonis Geographica, ed. M. Pinder, G. Parthey, Berlin 1860.

Roma e la Liguria Maritima: secoli IV-X. La capitale cristiana e una regione di confine, Atti del Corso e Catalogo della Mostra, Genova, 14 febbraio - 31 agosto 2003, ed. M. Marcenaro, Bordighera 2003.

S. Gregorii Magni Registrum epistolarum, vol. II, ed. D. Norberg (Corpus Christianorum, Serie Latina, CXL A e B), Tutnhout 1982.

Storia della chiesa, vol. III (La Chiesa tra Oriente e Occidente), ed. H. Jedin, Milano 1992.

\section{OpRacowania}

Andriani G., Giacomo Bracelli nella storia della geografia, „Atti della Società Ligure di Storia Patria" 1924, vol. LII, s. 155-161.

Archeologia Cristiana in Liguria, Aree ed edifici di culto tra IV e XI secolo, Soprintendenza Archeologia della Liguria, Genova s.d.

Balbi G., L'epistolario di Iacopo Bracelli, Genova 1969.

Christie N.J., Byzantine Liguria: an Imperial Province against the Longobards. A.D. 568-643, „Papers of the British School at Rome” 1990, vol. LVIII, s. 229-271.

Cosentino S., Storia dell'Italia bizantina (VI-XI secolo). Da Giustiniano ai Normanni, Bologna 2008.

De Negri T.O., Storia di Genova, Firenze 1985.

Dufour Bozzo C., La diocesi di Genova, Corpus della scrittura altomedievale, IV, Spoleto 1966.

Lusuardi Siena S., La Cattedrale di Santa Maria, [w:] Luni. Guida Archeologica, Sarzana 1985, s. 120-130.

Marcenaro M., Il battistero di Albenga. Le origini del primo cristianesimo nella Liguria marittima, Genova 1993.

Mennella G., Coccoluto G., Regio IX, Dertona-Libarna, Bari 1990.

Mennella G., Coccoluto G., Regio IX. Liguria reliqua trans et cis Appenninum, Bari 1995.

Murialdo G., Conclusioni: Il castrum di S. Antonino nell'Italia nord-occidentale in età bizantino-longobarda, [w:] Sant'Antonino: un insediamento fortificato della Liguria bizantina, ed. T. Mannoni, G. Murialdo, Bordighera 2001, s. 749-796.

Murialdo M., La contrazione insediativa altomedievale e l'abbadono del castrum, [w:] Sant'Antonino: un insediamento fortificato della Liguria bizantina, ed. T. Mannoni, G. Murialdo, Bordighera 2001, s. 669-682.

Origone S., La Liguria nell'età dell'esarcato, „Porphyra” 2006, Issue 8, s. 12-25, www.porphyra.it. 
Origone S., Liguria bizantina: 538-643, [w:] Polupleuros Nous, Miscellanea für Peter Schreines zu seinem 60. Geburtstag, hrsg. von C. Scholz, G. Makris, Leipzig 2000, s. 272-289.

Pistarino G., La Liguria: regione nazione, [w:] La capitale del mediterraneo, Bordighera 1993, s. 5-33.

Schreiner P., Bisanzio e Genova. Tentativo di un'analisi delle relazioni politiche, commerciali e culturali, [w:] Orbis Byzantinus. Byzanz und seine Nachbarn, Buçuresti 2013, s. 63-76.

Shepard J., Bunkers, Open Cities and Boats in Byzantine Diplomacy, [w:] Byzantium, its Neighbours and its Cultures, ed. D. Dzino, K. Parry, Leiden 2017, s. 11-44.

Zanini E., Le Italie bizantine. Territorio, insediamenti ed economia nella provincia bizantina d'Italia (V-VIII secolo), Bari 1998. 